Original Article

\title{
A survey on perception of homoeopathic undergraduate students towards learning environment in an Indian scenario
}

\author{
Subhranil Saha ${ }^{1}$, Munmun Koley $^{1}$, Aloke Ghosh ${ }^{2}$, Ramkumar Mondal ${ }^{3}$, \\ Jogendra Singh Arya ${ }^{1}$, Gurudev Choubey ${ }^{1}$
}

${ }^{1}$ Clinical Research Unit (Homeopathy), Siliguri, under CCRH, Govt. of India

2 Midnapore Homeopathic Medical College \& Hospital, Govt. of West Bengal, India

${ }^{3}$ Mahesh Bhattacharyya Homeopathic Medical College \& Hospital, Govt. of West Bengal

\begin{abstract}
This research was an attempt to understand the views of students of homoeopathic undergraduate schools in West Bengal, India and to identify areas of strength and weakness in the learning environment. An institutional, cross-sectional, observational study was carried out involving 430 students in May, 2013 in two Government homoeopathic medical colleges in West Bengal, India. A seven-item close-ended questionnaire with four point Likert scale was used to determine students' perceptions of the learning environment, intellectual climate and teacherstudent relationship in homoeopathic schools. The questionnaire generated seven subscales flexibility, student to student interaction, emotional climate, supportiveness, meaningful experience, organization, and breadth of interest. $46.5 \%$ students belonged to rural areas and Bengali was the mother tongue of $93.7 \%$ students. $39.5 \%$ preferred Bengali as the medium of instruction and group study was preferable to $77.9 \%$ students. $47.7 \%$ students were dissatisfied with the teaching process and $79.8 \%$ preferred the use of multimedia over conventional classroom teaching. Flexibility remained low (mean=1.9, $\mathrm{SD}=0.9$ ); meaningful experience (theoretical teaching) score was high (mean=2.6, $\mathrm{SD}=0.9$ ). Scores did not vary significantly $(\mathrm{P}>0.05)$ across the pre-clinical and clinical students, but few subscales produced significant differences individually among students of different years. Internal consistency scores of the scale remained questionable (Cronbach's a 0.310-0.446); however, the scale showed acceptable test-retest reliability (Cohen's $\mathrm{k}$ 0.680-0.838). This study emphasized the areas requiring improvement in homoeopathic school environment based on students' perspective. Changes in curriculum, faculty and infrastructure should be planned to improve students' satisfaction.
\end{abstract}

Keywords: education, environment, homeopathy, learning, questionnaire, students

\section{Introduction}

Evaluation is an integral part of medical education and is viewed as a means to facilitate improvements within medical education. This evaluation should be multi-dimensional, combining subjective and objective data to gather comprehensive information on teaching processes and learning outcomes [1, 2]. Scaled ratings provided by students are widely used to evaluate courses and teachers despite a large body of literature questioning the reliability and validity of this approach [3, 4]. In fact, many traditional evaluation forms using these scales assess 'teaching quality' in terms of student satisfaction with courses and organisational or structural aspects of teaching rather than the actual increase of knowledge or skills $[5,6]$. 
Using these surrogate parameters to appraise learning environment as a whole can be misleading as student ratings might be biased by many factors, e.g. initial interest of students [7], instructor reputation [8], instructor enthusiasm $[9,10]$ etc. Most studies addressing these confounders were quantitative in nature and did not allow any conclusions to be drawn on the decision-making process underlying the critical appraisal of courses and teachers by students.

Few qualitative studies have focused on student perceptions of course evaluation and processes potentially affecting numeric results. Faculty should know how students perceive the goals and consequences of evaluations, and any other factors that might influence ratings. Understanding how students view evaluation, define good teaching and arrive at course ratings are of utmost importance. Evaluation results may be considered as a guide to resource allocation within medical schools [2].

Public interest in and use of complementary and alternative medicine (CAM) including homeopathy has increased over the past decades, with an increase in numbers of adults visiting CAM practitioners [11]. Several countries have introduced CAM legislation and regulation to ensure citizens' freedom of right to make choices for their own healthcare, while at the same time ensuring safety. The safety of patients consulting with unregulated homeopaths and the quality of homeopathic treatment largely depends on the quality of undergraduate education. But there are few peer-reviewed papers describing educational initiatives in homeopathy and none describing whole programs [12-15]. Little pressure has been put on practitioners to harmonize education standards [16], but there are demands from both consumers and authorities to ensure high quality harmonized training standards [17].

Patients' trust in CAM practitioners is higher when they are certified than when they are not [18]. There has been some disagreement about and reluctance to standardizing education criteria in homeopathy; although systems of recognition and accreditation of courses have been recommended and introduced in some countries. Such systems aim at assessing and ensuring the quality of education [19, 20].

If course providers want to enable graduates to practice with the independent responsibility for their patients, then they must ensure sufficiently high quality of education. This raises the question: what is a sufficiently high quality of homeopathy education? Such a question should be better addressed by considering the specific competences practicing homeopaths should possess. This has been described e.g. in national occupational standards for homeopathy. Guidelines providing recommendations for the content of homeopathy education have been put forward by international organizations such as the European Central Council of Homeopaths. These guidelines do however not recommend extent of education. A report published by the Norwegian Directorate for Health recommended that in order for homeopaths to work as independent practitioners, with all the responsibilities this implies to ensure patient safety, such education should last four years full time. Although reports of unethical practice and malpractice are rare in homeopathy and guidelines for the bounds of competence of homeopaths have been established, future research should contribute by providing data which can further the development of the quality of undergraduate homeopathy education and to ensure that practitioners provide high quality homeopathic treatment within their bounds of competence [21].

As on April 1, 2011, there are a total of twelve degree homoeopathic medical colleges and hospital in West Bengal along with the National Institute of Homoeopathy, Salt Lake, Kolkata, run by the Government of India. Of the 12 state homoeopathic medical colleges, four are under the management of the State Government of West Bengal and the rest eight are private. Each of the Government colleges has admission capacity of 50 and all are affiliated to the University of Health Sciences, West Bengal. They run the course of Bachelor of Homoeopathic Medicine and Surgery (BHMS) of $4 \frac{1}{2}+1$ year's duration and also stipendiary post graduate course of homoeopathy, i.e. Doctor of Medicine (Homoeopathy) [MD (Hom)] of 3 years duration [22], under approval of Central Council of Homoeopathy, Govt. of India [23]. 


\section{Materials and methods}

An institutional, cross-sectional, observational survey was carried out in the second and third weeks of May, 2013 in two Government homoeopathic medical colleges of West Bengal, India - Mahesh Bhattacharyya Homoeopathic Medical College and Hospital and Midnapore Homoeopathic Medical College and Hospital. Permission was taken from the institutional ethics committee of the respective institutions prior conduct of the study.

Out of total 495 students in the two colleges, 430 participated and completed the questionnaire. For analytical purposes, students were divided into two groups - pre-clinical, including students from first year to fifth year and clinical, considering the internees. No universally accepted standardized questionnaire was available to evaluate homoeopathic undergraduate students' perception towards learning environment.

We used a questionnaire which was developed by Rothman AI and Ayoade F, 1970 [24] and Marshall RE, 1978 [25] and were tested earlier in different studies on medical [26, 27] and dental students [28] to be valid and reliable.

The directions to fill up the questionnaire were explained to all the students in detail by the research assistants. The questionnaire consisted of seven self-administered close-ended questions, each provided with a balanced four-point Likert scale, labeled as 'Seldom', 'Occasional', 'More often' and 'Very often'. Score of one, two, three and four were assigned respectively to these responses.

To evaluate the feasibility of application of the questionnaire in a large population, a pilot testing was done on 15 students before conducting the study. The instructions on the questionnaire were anonymous. It took $2-5$ minutes time to complete and all the data were collected from them by the research assistance. Instructions on the questionnaire promised anonymity. No patient identifiable information was required to ensure protection of patient's privacy. Also the filled in questionnaires were concealed by putting those inside opaque envelops which were sealed at the survey site by the patient him/herself. All these were collected by the research assistants and were sent to the data analyst. During analysis all the responses of each question were individually extracted and collected in data extraction sheets and analyzed thereafter.

Ten students from each year were requested to fill up the questionnaire again after an hour of the first round which helped in testing the test-retest reliability of the measuring instrument. Cohen's kappa (к) statistics was used to provide an exact agreement between two sets of scores. It also controlled for chance agreement between ratings. Kappa values greater than 0.75 indicate strong agreement beyond chance; and those between 0.40 and 0.74 reflect fair to good agreement.

One way analysis of variance (ANOVA) was computed as a comparison of responses of scales among different years to establish discriminant validity by using mean and standard deviation. By Cronbach's alpha, internal consistency was measured by comparison between total scores of scales and individual score of sub-scales.

Different online calculators were used for statistical computations; e.g. 'EndMemo' for skewness and kurtosis, 'Jumk.de' for mean, standard deviation, 'Wessa.Net' for Cronbach's alpha, 'DfreeLon.org' for kappa score, and 'DanielSoper' for one way ANOVA.

\section{Results}

Table 1 represents the description of the used questionnaire and its seven subscales, each provided with an example. 
Table 1: Used questionnaire - description and example of seven subscales

\begin{tabular}{|c|l|}
\hline Scales & Description and Example of items \\
\hline Flexibility & $\begin{array}{l}\text { Extent of opportunity for students to modify learning environment. } \\
\text { Example - Satisfaction regarding the easy approachability to teachers. }\end{array}$ \\
\hline $\begin{array}{c}\text { Student to } \\
\text { student } \\
\text { interaction }\end{array}$ & $\begin{array}{l}\text { Degree to which students mix socially and academically. } \\
\text { Example - Degree to which students mix socially and academically. }\end{array}$ \\
\hline $\begin{array}{c}\text { Emotional } \\
\text { Climate }\end{array}$ & $\begin{array}{l}\text { Way in which students experience affects their perception of dental education. } \\
\text { Example - Stress regarding the patients' quota given in various departments. }\end{array}$ \\
\hline $\begin{array}{c}\text { Supportiveness } \\
\text { Megree of concern expressed and support provided by faculty. } \\
\text { Example - Support provides by faculty to the students for study. }\end{array}$ & $\begin{array}{l}\text { Extent to which students learning activities are perceived to be relevant to the practice } \\
\text { of homoeopathy. } \\
\text { Example - The teaching based on theoretical knowledge. }\end{array}$ \\
\hline $\begin{array}{c}\text { Organization } \\
\text { Interest }\end{array}$ & $\begin{array}{l}\text { Degree of coherence of educational experience within the curriculum. } \\
\text { Example - Difficulty in co-relating subjects of previous year with those of the next year. }\end{array}$ \\
\hline $\begin{array}{l}\text { Breadth of } \\
\text { outside the regular course work. } \\
\text { Example - The knowledge gain in the college helps to accustom to various challenges in } \\
\text { life. }\end{array}$ \\
\hline
\end{tabular}

Table 2 reflects the socio-demographic data of the population. Mean age of the participants in this survey was 22.8 years $(\mathrm{SD}=2.4)$. Male and female ratio was almost the same, i.e. 214:216. A total of $200(46.5 \%)$ students belonged to rural areas and others were almost equally distributed in urban ( $\mathrm{n}=117,27.2 \%)$ and semi-urban area $(n=113,26.3 \%)$. The local vernacular Bengali was the first language of most of the students $(n=403$, 93.7\%). Bengali ( $\mathrm{n}=170,39.5 \%)$ was the most preferred language among the students, but a considerable percentage of students preferred combination $(\mathrm{n}=135,31.4 \%)$ of both Bengali and English. Among the students, group study method was the most popular $(\mathrm{n}=335,77.9 \%)$. The overall satisfaction regarding teaching remained poor. Most of the students were dissatisfied ( $\mathrm{n}=205,47.7 \%)$, in comparison with satisfied ones $(n=133,30.9 \%)$. A large number of students preferred use of multimedia in teaching $(n=343,79.8 \%)$ over conventional classroom teaching $(\mathrm{n}=73,16.9 \%)$.

Table 3 shows descriptive statistics of perception of learning environment. The response of each scale was expressed by mean and standard deviation. The mean overall flexibility was 1.9; mean scores of student to student interaction, emotional climate and supportiveness were the same of 2.5; and that for meaningful experience was 2.6; for organization were 2.4, and for breadth of interest were 2.5. The result also showed that the students' comfort level was quite low when approaching their teachers $(1.9 \pm 0.9)$ and another problematic finding was that the students considered facing teaching based on theoretical grounds only $(2.6 \pm$ $0.9)$. 
Table 2: Socio-demographic data $(n=430)$

\begin{tabular}{|c|c|}
\hline Age $(\mathrm{M} \pm \mathrm{SD})$ & $22.8 \pm 2.4$ \\
\hline Sex; n (\%) & \\
\hline Male & $214(49.8 \%)$ \\
\hline Female & $216(50.2 \%)$ \\
\hline Mother tongue; n (\%) & \\
\hline Bengali & $403(93.7 \%)$ \\
\hline Hindi & $24(5.6 \%)$ \\
\hline Urdu & $3(0.7 \%)$ \\
\hline Residence; n (\%) & \\
\hline Urban & $117(27.2 \%)$ \\
\hline Semi-urban & $113(26.3 \%)$ \\
\hline Rural & $200(46.5 \%)$ \\
\hline Preferred language of instruction; n (\%) & \\
\hline Bengali & $170(39.5 \%)$ \\
\hline English & $125(29.1 \%)$ \\
\hline Combined & $135(31.4 \%)$ \\
\hline Preferred study method; n (\%) & \\
\hline Alone & $95(22.1 \%)$ \\
\hline Group & $335(77.9 \%)$ \\
\hline Overall satisfaction; n (\%) & \\
\hline Satisfied & $133(30.9 \%)$ \\
\hline Dissatisfied & $205(47.7 \%)$ \\
\hline Uncertain & $92(21.4 \%)$ \\
\hline Mode of teaching; n (\%) & \\
\hline Conventional classroom teaching & $73(16.9 \%)$ \\
\hline Multimedia & $343(79.8 \%)$ \\
\hline Others & $14(3.3 \%)$ \\
\hline
\end{tabular}

Table 3: Descriptive statistics of perception of learning environment $(n=430)$

\begin{tabular}{|l|c|c|c|}
\hline Scales & Overall value $($ Mean $\pm \mathrm{SD})$ & Skewness & Kurtosis \\
\hline Flexibility & $1.9 \pm 0.9$ & 0.705 & 2.707 \\
\hline $\begin{array}{l}\text { Student to student } \\
\text { interaction }\end{array}$ & $2.5 \pm 0.9$ & 0.099 & 2.300 \\
\hline Emotional climate & $2.5 \pm 0.9$ & 0.055 & 2.286 \\
\hline Supportiveness & $2.5 \pm 0.9$ & -0.126 & 2.093 \\
\hline Meaningful experience & $2.6 \pm 0.9$ & -0.091 & 2.237 \\
\hline Organization & $2.4 \pm 0.8$ & -0.032 & 2.350 \\
\hline Breadth of interest & $2.5 \pm 1$ & 0.038 & 1.929 \\
\hline
\end{tabular}


Table 4 shows the comparison of perception between pre-clinical and clinical students. Insignificant differences were elicited between the perception of learning environment of pre-clinical and clinical students.

Table 4: Comparison between perception of pre-clinical and clinical students

\begin{tabular}{|l|c|c|c|c|}
\hline Scales & $\begin{array}{c}\text { Pre-clinical } \\
(\mathrm{M} \pm \mathrm{SD})\end{array}$ & $\begin{array}{c}\text { Clinical } \\
(\mathrm{M} \pm \mathrm{SD})\end{array}$ & $t$ value & $P$ value \\
\hline Flexibility & $1.9 \pm 0.9$ & $1.9 \pm 1.0$ & 0.495 & 0.621 \\
\hline Student to student interaction & $2.5 \pm 0.8$ & $2.4 \pm 0.9$ & 1.185 & 0.237 \\
\hline Emotional climate & $2.5 \pm 0.9$ & $2.4 \pm 0.8$ & 0.366 & 0.714 \\
\hline Supportiveness & $2.5 \pm 0.9$ & $2.5 \pm 1.1$ & 0.526 & 0.599 \\
\hline Meaningful experience & $2.6 \pm 0.9$ & $2.5 \pm 0.8$ & 0.391 & 0.696 \\
\hline Organization & $2.4 \pm 0.9$ & $2.4 \pm 0.6$ & 0.457 & 0.648 \\
\hline Breadth of interest & $2.5 \pm 0.9$ & $2.3 \pm 1.0$ & 1.248 & 0.213 \\
\hline
\end{tabular}

Independent $t$ test; $\mathrm{P}<0.05$ (two tailed; $95 \% \mathrm{CI}$ ) is considered statistically significant

Table 5 represents comparison among individual perception of all the years. Significant differences were observed in flexibility $(\mathrm{F}=10.216, \mathrm{P}=0.000)$; student to student interaction $(\mathrm{F}=8.579, \mathrm{P}=0.000)$; emotional climate $(\mathrm{F}=2.475, \mathrm{P}=0.032)$; meaningful experience $(\mathrm{F}=3.497, \mathrm{P}=0.004)$ and organization $(\mathrm{F}=2.947, \mathrm{P}=0.013)$. Non-significant results were found in supportiveness $(\mathrm{F}=0.232, \mathrm{P}=0.949)$ and breadth of interest $(\mathrm{F}=1.450$, $\mathrm{P}=0.205)$, i.e. these two did not vary significantly among the groups.

Table 5: Comparison of perception scores among students of different years; $n=430$ (M \pm SD)

\begin{tabular}{|l|c|c|c|c|c|c|c|c|}
\hline Scales & $\begin{array}{c}1^{\text {st }} \text { year } \\
(\mathrm{n}=72)\end{array}$ & $\begin{array}{c}2^{\text {nd }} \text { year } \\
(\mathrm{n}=44)\end{array}$ & $\begin{array}{c}3^{\text {rd }} \text { year } \\
(\mathrm{n}=92)\end{array}$ & $\begin{array}{c}4^{\text {th }} \text { year } \\
(\mathrm{n}=92)\end{array}$ & $\begin{array}{c}5^{\text {th }} \text { year } \\
(\mathrm{n}=62)\end{array}$ & $\begin{array}{c}\text { Internee } \\
(\mathrm{n}=68)\end{array}$ & F value & $P$ value \\
\hline Flexibility & $2.5 \pm 0.9$ & $1.9 \pm 0.9$ & $1.7 \pm 0.7$ & $1.7 \pm 0.7$ & $1.8 \pm 0.7$ & $1.9 \pm 1.0$ & 10.216 & $0.000^{*}$ \\
\hline $\begin{array}{l}\text { Student to student } \\
\text { interaction }\end{array}$ & $2.9 \pm 0.9$ & $2.2 \pm 0.7$ & $2.2 \pm 0.8$ & $2.6 \pm 0.7$ & $2.7 \pm 0.8$ & $2.4 \pm 0.9$ & 8.579 & $0.000^{*}$ \\
\hline Emotional climate & $2.3 \pm 0.9$ & $2.8 \pm 0.7$ & $2.6 \pm 0.9$ & $2.4 \pm 0.9$ & $2.5 \pm 0.9$ & $2.4 \pm 0.8$ & 2.475 & $0.032^{*}$ \\
\hline Supportiveness & $2.6 \pm 0.9$ & $2.5 \pm 0.9$ & $2.6 \pm 0.9$ & $2.5 \pm 0.9$ & $2.5 \pm 0.9$ & $2.5 \pm 1.1$ & 0.232 & 0.949 \\
\hline $\begin{array}{l}\text { Meaningful } \\
\text { experience }\end{array}$ & $2.2 \pm 0.7$ & $2.6 \pm 0.7$ & $2.6 \pm 0.9$ & $2.7 \pm 0.9$ & $2.7 \pm 1.0$ & $2.5 \pm 0.8$ & 3.497 & $0.004^{*}$ \\
\hline Organization & $2.2 \pm 0.9$ & $2.4 \pm 0.8$ & $2.2 \pm 0.9$ & $2.6 \pm 0.8$ & $2.4 \pm 0.8$ & $2.4 \pm 0.6$ & 2.947 & $0.013^{*}$ \\
\hline Breadth of interest & $2.7 \pm 0.9$ & $2.4 \pm 1.0$ & $2.5 \pm 0.9$ & $2.4 \pm 1.0$ & $2.5 \pm 0.9$ & $2.3 \pm 1.0$ & 1.450 & 0.205 \\
\hline
\end{tabular}

*Significant; $\mathrm{P}<0.05$ (two tailed; 95\% CI) is considered statistically significant

Table 6 shows the evaluation of internal consistency of the used questionnaire, which remained uncertain (0.310-0.446, unacceptable). Though the used questionnaire was found to be reliable in earlier studies on medical and dental students, a modified novel version needs to be explored on perspective of homeopathic undergraduate students in future studies. 
Table 6: Internal consistency evaluated by Cronbach's alpha $(\mathrm{n}=430)$

\begin{tabular}{|l|c|}
\hline Scales & Cronbach's alpha \\
\hline Flexibility & 0.414 \\
\hline Student to student interaction & 0.446 \\
\hline Emotional climate & 0.428 \\
\hline Supportiveness & 0.436 \\
\hline Meaningful experience & 0.431 \\
\hline Organization & 0.310 \\
\hline Breadth of interest & 0.442 \\
\hline
\end{tabular}

Table 7 reflects test-retest reliability of each question by Cohen's Kappa (к). Most of these values showed strong agreement $(0.788-0.795)$ and few showed fair to moderate agreement $(0.68-0.748)$ with previous responses.

Table 7: Test retest reliability of each question by Cohen's Kappa $(n=60)$

\begin{tabular}{|l|c|}
\hline Scales & Cohen's Kappa \\
\hline Flexibility & 0.788 \\
\hline Student to student interaction & 0.838 \\
\hline Emotional climate & 0.812 \\
\hline Supportiveness & 0.744 \\
\hline Meaningful experience & 0.748 \\
\hline Organization & 0.680 \\
\hline Breadth of interest & 0.795 \\
\hline
\end{tabular}

\section{Discussion}

Bengali was the mother tongue of most of the students participated in the survey, and, naturally Bengali was the preferred medium of instruction. Remarkably, a considerable percentage chose combined language as medium of instruction. It has been seen that working memory is often poorer for a second language [29]. In medical education, most information is communicated verbally, often to large groups of students. Consequently, listening abilities and language comprehension are critical to learning and require both auditory perception and auditory working memory (WM) skills. It has been widely reported that WM capacity may be limited for students who are learning in an environment where the language of instruction is not their native language and this appears to be due to demands on WM resources in the second language [30-38]. The relationship between WM capacity and academic achievement has been well studied in university students and adults [39-42]. 
Several factors have been shown to influence undergraduate students' study approaches, with students adopting strategies in accordance with their interpretations of the requirements of the tasks assigned within a specific learning environment [43]. These interpretations varied depending on students' perception of the academic quality of a course and the nature of the curriculum [44], students' implicit theories of learning on entering higher education [45] and the learning environment to which students are exposed [46]. However, these interpretations alone do not explain the full range of students' intentions and motivations with respect to studying [47]. Students' perceptions of the environment in which they learn and are assessed also interfere with their choice of the study approaches.

However, it is hard to predict which choices students will make [48, 49]. It appears that there is a variety of factors influencing how students tackle their academic work. These factors can lead to swings in students' appraisals of the usefulness of different study approaches.

Majority of students preferred the use of multimedia in teaching. Multimedia provides an efficient method to teach psychomotor skills to students entering the health professions. Reponses relative to instructional multimedia emphasized efficiency, processing level, autonomy, and detail of instruction compared to live presentation [50].

Teachers played a key role, particularly as assessors, clinical supervisors and as a source of stress to students. Nevertheless it is always hard to criticize teachers and this will have biased the reporting of students. The definition of a successful individual learning environment might substantially differ between students and medical educators.

Obviously, satisfaction with teaching is likely to result in higher motivation to learn, thus rendering student satisfaction an important moderator of learning behavior and, eventually, learning success. Teaching quality is believed to be dependent on content, process, teacher and student characteristics as well as learning outcome, with an emphasis on the latter. Given the importance of the individual teacher, it does seem natural for students to favour learning environment entailing direct consequences for specific teachers.

Published reports of instruments to increase motivation to teach usually refer to positive reinforcement measures [51-53]. We stress upon the relevance of teacher training with regard to improving teaching quality and increasing student motivation to learn. Allocation of rewards and incentives for good teaching to individual teachers may be viewed as a potential way to enhance teachers' involvement. And, in addition to assessing structural aspects of teaching, evaluation tools need to adequately address learning outcome. The use of reliable and valid evaluation methods is a prerequisite for resource allocation to individual teachers based on evaluation results.

This is a useful adjunct to quantitative statistical methods [54-56]. However, while providing in depth information on individual opinions and specific problems, they may not be fully representative of the group of interest. In order to further elucidate student attitudes towards evaluation of learning environment, focus group interviews can be conducted, addressing student perceptions of learning environment, use of evaluation tools, individual benchmarks for teaching quality and the possible consequences of the evaluation results. In addition to procedural and structural aspects of teaching, learning outcome is viewed as an important target for evaluation. Accordingly, evaluation tools need to adequately address learning outcome. However, a number of contributions revealed that students did not use specific pre-defined criteria of good teaching (i.e., 'benchmarks') when appraising teaching quality. In the absence of such criteria, students referred to their gut feeling and single outstanding (negative or positive) events as major contributors to their overall course ratings. 
Qualitative studies might be of interest to faculty and program directors who need to be aware of the assumptions and confounders underlying student ratings. This is of particular importance if evaluation results are used to guide resource allocation within medical schools. Rather than producing statistically representative data, qualitative research facilitates easy identification of general trends or patterns regarding the attitudes of the target group, establishing 'functional and psychological representativeness'. However, the assumption that data collection was relatively comprehensive is supported by the identification of a large number of aspects known to be relevant from more representative research. To date, very few qualitative studies have focused on student perceptions of evaluation.

Ideally, assessment in the clinical years should focus on students' ability to organize thoughts, link theoretical knowledge to patients' management, communicate with patients and the environment and elaborate on patients' conditions. It should also focus on students' clinical skills and work. Deep-learning approaches, including knowledge integration, writing summaries and self-testing are important to prepare students for assessment, clinical problem solving and safe patient management [57-59]. However, since students are known to swing between different study strategies in response to different environmental and contextual factors, they may occasionally use strategies involving "memorizing without understanding" [60] and "fragmented knowledge" [61].

The term "community of practice" was first described by Lave and Wenger as learning through practice and participation. It describes the function of a group of people who have a variety of experiences but share an interest or a profession. They share information and experiences, learn from each other, and have similar opportunities to develop [62]. Everybody is involved in a number of communities of practice whether at work, school, or home. Their structural characteristics are defined as a domain of knowledge, a notion of community and a practice [63]. It appears that the studied students' learning in the clinical context and their social experiences are a new example of "community of practice" that can be called "community of clinical practice". In this research, we have evaluated students' actions and interactions in the "community of clinical practice". In the community of clinical practice, teachers played a crucial role, particularly in assessment and clinical supervision and can be a potential source of stress to students. They were unaware of the potential negative and positive consequences of their actions as supervisors and assessors with regard to students' learning strategies. Awareness enhancement through an effective faculty training program is required to promote desired students' study strategies. Further promotion of desired study strategies can be obtained through clinical curriculum modification. The emphasis should be on more supervisors and supervision role, more clinical involvement, more clinical assessment and constructive alignment [64].

\section{Conclusion}

Despite a wide use of various evaluation tools in medical sector, little was known about homoeopathic students' perceptions regarding the desired learning environment. We reported on a novel evaluation tool aimed at determining the same. Students enumerated several quality indicators of teaching and learning that encompassed a wide range of parameters pertaining to teachers, courses and the homoeopathic medical school as a whole. Teacher characteristics appear to be crucial for student perceptions of teaching quality. While more research into this issue is warranted, it may be hypothesized that empathic and enthusiastic teachers can improve students' motivation to learning. We highly recommend the use of modern educational methods in steering the teaching away from information transfer and toward an engaged group-learning experience. As the reliability of the used questionnaire remained questionable in our survey, the findings need to be confirmed in further studies in order to assess the generalizability of our results to other institutions and study subjects. While this study generated a set of variables deemed important by students, further quantitative and qualitative studies are needed to estimate the actual impact each of these factors has on student ratings of teaching quality. Finally, future research should be directed at the perspectives of teachers and program directors on learning environment. 


\section{Acknowledgement}

The authors would like to acknowledge Dr. Rajkumar Manchanda, Director General, Central Council for Research in Homoeopathy, New Delhi, Govt. of India for his constant encouragement and silent support all through the study. We are also grateful to Dr. Amitava Biswas, Principal, Mahesh Bhattacharyya Homoeopathic Medical College \& Hospital, Govt. of West Bengal, India and Dr. Chapal Kumar Bhattacharyya, Principal in-Charge, Midnapore Homoeopathic Medical College \& Hospital, Govt. of West Bengal, India for giving permission to conduct the survey in their institutions.

\section{References}

[1] McOwen KS, Bellini LM, Morrison G, Shea JA: The Development and Implementation of a Health-SystemWide Evaluation System for Education Activities: Build It and They Will Come. Acad Med 2009,84:1352-9.

[2] Herzig S, Marschall B, Nast-Kolb D, Soboll S, Rump LC, Hilgers RD. Positionspapier der nordrheinwestfälischen Studiendekane zur hochschulvergleichenden leistungsorientierten Mittelvergabe für die Lehre. GMS Z Med Ausbild 2007, 24:Doc109.

[3] McKeachie W. Student ratings; the validity of use. Am Psychol 1997,52:1218-1225.

[4] Raupach T, Schiekirka S, Münscher C, Beibarth T, Himmel W, Burckhardt G, Pukrop T. Piloting an outcome-based programme evaluation tool in undergraduate medical education. GMS Z Med Ausbild 2012, 29:Doc44.

[5] Braun E, Leidner B. Academic course evaluation: Theoretical and empirical distinctions between self-rated gain in competences and satisfaction with teaching behavior. Eur Psychol 2009, 14:297-306.

[6] Cantillon P. GUEST EDITORIAL: Evaluation: beyond the rhetoric. J Eval Clin Pract 1999, 5:265-8.

[7] Prave RS, Baril GL. Instructor ratings: Controlling for bias from Initial student interest. J Educ Bus 1993, 68:362-6.

[8] Griffin BW. Instructor Reputation and Student Ratings of Instruction. Contemp Educ Psychol 2001, 26:534-52.

[9] Naftulin DH, Ware JE, Donnelly FA. The Doctor Fox Lecture: A Paradigm of Educational Seduction. J Med Educ 1973, 48:630-5.

[10] Marsh HW, Ware JE. Effects of expressiveness, content coverage, and incentive on multidimensional student rating scales: New interpretations of the Dr. Fox effect J Educ Psychol 1982, 74:126-34.

[11] Ernst E. Is homeopathy a clinically valuable approach? Trends in Pharmacological Science 2005 Nov;26(11):547-8.

[12] Teixeira MZ, Lin CA, de Arruda Martins M. Homeopathy and acupuncture teaching at the University of Sao Paulo Medical School: the undergraduates' attitudes. J Alt Complement Med 2005;11(5):787-92. 
[13] Thompson TDB, Thompson EA. "In at the deep end": an intensive foundation training in homeopathy for medical students. Homeopathy 2009;98:107-13.

[14] Owen D. Learning experiences—what works for postgraduates. Homeopathy 2002;91(2):95-8.

[15] Witt CM, Brinkhaus B, Willich SN. Teaching complementary and alternative medicine in a reform curriculum. Forsch Komplementmed 2006;13(6):342-8.

[16] Raupach T, Munscher C, Beissbarth T, Burckhardt G, Pukrop T. Towards outcome-based programme evaluation: Using student comparative self assessments to determine teaching effectiveness. Med Teach 2011;33:446-53.

[17] Kogan JR, Shea JA. Course evaluation in medical education. Teach Teach Educ 2007, 23:251-64.

[18] Van den Brink-Muinen A, Rijken PM. Does trust in health care influence the use of complementary and alternative medicine by chronically ill people? BMC Public Health 2006;6:188.

[19] Kelner M, Wellman B,Welsh S, Boon H. How far can complementary and alternative medicine go? The case of chiropractic and homeopathy. Soc Sci Med 2006;63(10):2617-27.

[20] Shahjahan R. Standards of education, regulation, and market control: perspectives on complementary and alternative medicine in Ontario, Canada. J Altern Complement Med 2004;10(2):409-12.

[21] Viksveen P, Steinsbekk A. Undergraduate homeopathy education in Europe and the influence of accreditation. Homeopathy 2011;100:253-8.

[22] http://www.wbhealth.gov.in; official website of Department of Health \& Family Welfare, Government of West Bengal; Accessed on June 5, 2013.

[23] http://www.cchindia.com; official website of Central Council of Homoeopathy, Government of India; Accessed on June 5, 2013.

[24] Rothman AI, Ayoade F. The development of a learning environment: a questionnaire for use in curriculum evaluation. J Med Educ 1970;45(10):754-9.

[25] Marshall RE. Measuring the medical school learning environment. J Med Educ 1978;53(2):98-104.

[26] Feletti GI, Clarke RM. Construct validity of a learning environment survey for medical schools. Educational and Psychological Measurement 1981;41(3):875-82.

[27] Feletti GI, Clarke RM. Review of psychometric features of the medical school learning environment survey. Med Educ 1981;15(2):92-6.

[28] Jain L, Jain M, Mathur A, Paiwal K, Duraiswamy P, Kulkarni S. Perceptions of dental students towards learning environment in an Indian scenario. Dent Res J (Isfahan) 2010 Summer-Autumn;7(2):56-63. 
[29] Mann C, Canny BJ, Reser DH, Rajan R. Poorer verbal working memory for a second language selectively impacts academic achievement in university medical students. PeerJ 2013;1:e22; DOI 10.7717/peerj.22.

[30] Service E. Phonology, working memory, and foreign-language learning. The Quarterly Journal of Experimental Psychology Section A: Human Experimental Psychology 1992;45(1):21-50.

[31] Miyake A, Friedman NP. Individual differences in second language proficiency: working memory as language aptitude. In: Healy AF, Bourne LE, eds. Foreign language learning: psycholinguistic studies on training and retention. Mahwah, NJ: L. Erlbaum Associates, 1998.

[32] Kroll JF, Michael E, Tokowicz N, Dufour R. The development of lexical fluency in a second language. Second Language Research 2002;18(2):137-71.

[33] Mackey A, Philp J, Egi T, Fujii A, Tatsumi T. Individual differences in working memory, noticing interactional feedback and L2 development. In: Robinson P, ed. Individual differences and instructed language learning. Philadelphia: J Benjamins Pub 2002;181-210.

[34] Service E, Simola M, Mets anheimo O, Maury S. Bilingual working memory span is affected by language skill. Journal of Cognitive Psychology 2002;14(3):383-408.

[35] Tokowicz N, Michael EB, Kroll JF. The roles of study-abroad experience and working-memory capacity in the types of errors made during translation. Bilingualism: Language and Cognition 2004;7:255-72.

[36] McDonald JL. Beyond the critical period: processing-based explanations for poor grammaticality judgment performance by late second language learners. Journal of Memory and Language 2006;55(3):381401.

[37] Sunderman G, Kroll JF. When study-abroad experience fails to deliver: the internal resources threshold effect. Applied Psycholinguistics 2009;30(1):79-99.

[38] Andersson U. The contribution of working memory capacity to foreign language comprehension in children. Memory 2010;18(4):458-72.

[39] Daneman M, Carpenter PA. Individual differences in working memory and reading. Journal of Verbal Learning and Verbal Behavior 1980;19(4):450-66.

[40] Swanson HL. Short-term memory and working memory. Journal of Learning Disabilities 1994;27(1):3450.

[41] Daneman M, Hannon B. Using working memory theory to investigate the construct validity of multiplechoice reading comprehension tests such as the SAT. Journal of Experimental Psychology: General 2001;130(2):208-23.

[42] Tolar TD, Lederberg AR, Fletcher JM. A structural model of algebra achievement: computational fluency and spatial visualisation as mediators of the effect of working memory on algebra achievement. Educational Psychology 2009;29(2):239-66. 
[43] Marton F, Saljo R. Approaches to learning. In Marton F, Hounsell DJ, Entwistle NJ (Eds.), The experience of learning, 2nd ed., pp. 39-58. Edinburgh, UK: Scottish Academic, 1997.

[44] Richardson JT, Dawson L, Sadlo G, Jenkins V, McInnes J. Perceived academic quality and approaches to studying in the health professions. Medical Teacher 2007; 29(5):108-16.

[45] Edmunds R, Richardson JE. Conceptions of learning, approaches to studying and personal development in UK higher education. British Journal of Education 2008;79:295-309.

[46] Reid WA, Duvall E, Evans P. Can we influence medical students' approaches to learning? Medical Teacher 2005;27(5):401-7.

[47] Mattick K, Knight L. High-quality learning: Harder to achieve than we think? Medical Education 2007;41(7):638-44.

[48] Mattick K, Knight L. High-quality learning: Harder to achieve than we think? Medical Education 2007;41(7):638-44.

[49] Mattick K, Knight L. The importance of vocational and social aspects of approaches to learning for medical students. Advances in Health Sciences Education Theory Practice 2008;14(5):629-44.

[50] Smith Jr AR, Cavanaugh C, Moore WA. Instructional multimedia: An investigation of student and instructor attitudes and student study behavior. BMC Medical Education 2011;11:38.

[51] Pessar LF, Levine RE, Bernstein CA, Cabaniss DS, Dickstein LJ, Graff SV, et al. Recruiting and rewarding faculty for medical student teaching. Acad Psychiatr 2006, 30:126-129.

[52] Olmesdahl PJ. Rewards for teaching excellence: practice in South African medical schools. Med Educ 1997, 31:27-32.

[53] Brawer J, Steinert Y, St-Cyr J, Watters K, Wood-Dauphinee S. The significance and impact of a faculty teaching award: disparate perceptions of department chairs and award recipients. Med Teach 2006, 28:614-7.

[54] Clarke PN, Yaros PS. Research blenders: commentary and response. Transitions to new methodologies in nursing sciences. Nurs Sci Q 1988,1:147-151.

[55] Johnson RB, Onwuegbuzie AJ. Mixed Methods Research: A research paradigm whose time has come. Educ Res 2004, 33:12-26.

[56] Morgan WF. Focus Groups. Ann Rev Sociol 1996, 22:129-152.

[57] Groves M. Problem-based learning and learning approach: Is there a relationship? Advances in Health Sciences Education 2005;10:315-26.

[58] McParland M, Noble LM, Livingstone G. The effectiveness of problem-based learning compared to traditional teaching in undergraduate psychiatry. Medical Education 2004;38(8):859-67. 
[59] Newble DI, Clarke RM. The approaches to learning of students in a traditional and in an innovative problem-based medical school. Medical Education 1986;20(4):267-73.

[60] Meyer JHF. Variation in contrasting forms of "memorising" and associated observables. British Journal of Educational Psychology 2000;70:163-76.

[61] Meyer JHF. Study orchestration: The manifestation, interpretation and consequences of contextualised approaches to studying. Higher Education 1991;22:297-316.

[62] Lave J, Wenger E. Situated learning: Legitimate peripheral participation. Cambridge, UK: Cambridge University Press, 1990.

[63] Wenger E. Communities of practice learning, meaning, and identity. Cambridge, UK: Cambridge University Press, 1998.

[64] Al Kadri HMF, Al-Moamary MS, Elzubair M, Magzoub ME, AlMutairi A, Roberts C, van der Vleuten C. Exploring factors affecting undergraduate medical students' study strategies in the clinical years: a qualitative study. Adv in Health Sci Educ 2011;16:553-67.

\title{
Pesquisa de opinião sobre a percepção dos estudantes de homeopatía, sobre o ambiente de aprendizagem, no contexto indiano
}

\begin{abstract}
RESUMO
Introdução e objetivo: Este estudo buscou entender a percepção de estudantes de faculdades homeopáticas em Bengala Ocidental, Índia, e identificar os pontos fortes e fracos do ambiente de aprendizagem. Métodos: Estudo transversal com desenho observacional realizado en maio de 2013 con 430 voluntarios em duas faculdades públicas de medicina homeopática em Bengala Ocidental, Índia. Um questionário com 7 ítens respondidos em uma escala tipo Likert de 4 pontos foi aplicada para determinar a percepção dos voluntários a respeito de seu ambiente de aprendizagem, clima intelectual e relação aluno-professor. O questionário gerou 7 sub-escalas flexibilidade, interação entre estudantes, clima emocional, suporte, experiência significativa, organização e amplitude de interesses. Cerca de 46,5\% dos estudantes procedía de áreas rurais, a língua materna de $93,7 \%$ era bengalí, $39,5 \%$ prefería que se falasse bengalí nas aulas, $77,9 \%$ prefería trabalhar em grupo, $47,7 \%$ se manifestaram insatisfeitos com o modelo de ensino e 79,8\% preferíam as técnicas multimídias comparadas às convencionais. A flexibilidade foi baixa (media= 1,9 , desvio padrão $\mathrm{DE}=0,9$ ); a pontuação da experiência significativa (ensino teórico) foi elevada (média $=2,6, \mathrm{DE}=0,9)$. As pontuações não apresentaram diferenças significativas $(\mathrm{p}>0,05)$ entre os estudiantes em fase preclínica e clínica, porém, algumas sub-escalas individuais apresentaram diferenças significativas entre os estudantes dos diversos cursos. A consistência interna do questionário é duvidosea (coeficiente $\alpha$ de Cronbach: 0,310-0,446), porém, a confiabilidade do teste-reteste se mostrou aceitável ( $\kappa$ de Cohen: 0,680-0,838). Conclusões: Este estudo assinala as áreas que devem ser melhoradas na aprendizagem da homeopatía desde a perspectiva dos estudantes. Mudanças nos programas de estudos, corpo docente e infraestructura são necessárias para melhoras a satisfação dos alunos.
\end{abstract}

Palabras chave: educação, ambiente, homeopatía, aprendizagem, questionário, estudantes 


\title{
Encuesta sobre la percepción de estudiantes de homeopatía de pregrado acerca del ambiente de aprendizaje en contexto indiano
}

\begin{abstract}
RESUMEN
Introducción y objetivo: Este estudio buscó entender la percepción de estudiantes de pregrado en facultades homeopáticas en Bengala Occidental, India, e identificar los puntos fuertes y débiles del ambiente de aprendizaje. Métodos: Estudio transversal con diseño observacional realizado en mayo de 2013 con 430 voluntarios en dos facultades públicas de medicina homeopática en Bengala Occidental, India. Un cuestionario con 7 ítems respondidos en una escala tipo Likert de 4 puntos fue aplicada para determinar la percepción de los voluntarios acerca de su ambiente de aprendizaje, clima intelectual y relación alumno-profesor. El cuestionario generó 7 sub-escalas flexibilidad, interacción entre estudiantes, clima emocional, soporte, experiencia significativa, organización y amplitud de intereses. Cerca del 46,5\% de los estudiantes procedía de áreas rurales, la lengua materna del $93,7 \%$ era bengalí, un 39,5\% prefería que se hablase bengalí en las clases, el $77,9 \%$ prefería trabajar en grupo, $47,7 \%$ se manifestaron insatisfechos con el modelo de enseñanza y $79,8 \%$ preferían las técnicas multimedios comparadas a las convencionales. La flexibilidad fue baja (media $=1.9$, desviación estándar $-\mathrm{DE}=0,9$ ); el puntaje de experiencia significativa (enseñanza teórica) fue elevado (media $=2,6, \mathrm{DE}=0,9$ ). Los puntajes no presentaron diferencia significativa $(p>0,05)$ entre los estudiantes en fase preclínica y clínica, sin embargo, algunas sub-escalas individuales presentaron diferencias significativas entre los estudiantes de los diversos cursos. La consistencia interna del cuestionario es dudosa (coeficiente $\alpha$ de Cronbach: 0,310-0,446), sin embargo, la confiabilidad del test-retest se mostró aceptable ( $\kappa$ de Cohen: 0,6800,838). Conclusiones: Este estudio señala las áreas que deben ser mejoradas en el aprendizaje de la homeopatía desde la perspectiva de los estudiantes. Cambios en el programa de estudios, cuerpo docente e infraestructura son necesarios para mejorar la satisfacción de los alumnos.
\end{abstract}

Palabras clave: educación, ambiente, homeopatía, aprendizaje, cuestionario, estudiantes

\section{(c)) BY-NC-ND Licensed to GIRI}

Support: authors declare that this study received no funding

Conflict of interest: authors declare there is no conflict of interest

Received: June 10th, 2013 ; Revised: June 19 ${ }^{\text {th }}$, 2013; Published: June 30th 2013.

Correspondence author: Subhranil Saha, drsubhranilsaha@hotmail.com

How to cite this article: Saha S, Koley M, Ghosh A, Mondal R, Arya JS, Choubey G. A survey on perception of homoeopathic undergraduate students towards learning environment in an Indian scenario. Int J High Dilution Res [online]. 2013 [cited YYYY Month dd]; $12(43): \quad 62-76 . \quad$ Available from: http://www.feg.unesp.br/ ojs/index.php/ijhdr/article/view/633/635 